\title{
Cucurbita Plants: From Farm to Industry
}

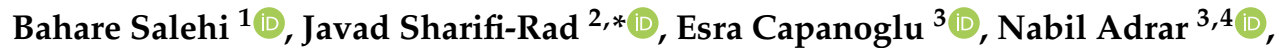

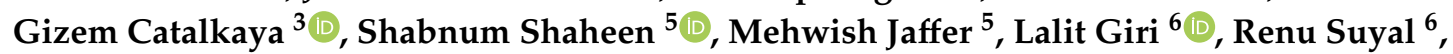 \\ Arun K Jugran ${ }^{7}$, Daniela Calina ${ }^{8}\left({ }^{1}\right.$, Anca Oana Docea ${ }^{9}$, Senem Kamiloglu ${ }^{10}(\mathbb{D}$, \\ Dorota Kregiel 11 $^{1 D}$, Hubert Antolak ${ }^{12}$ (D), Ewelina Pawlikowska 11(D), Surjit Sen 12,13, \\ Krishnendu Acharya ${ }^{12}$, Moein Bashiry ${ }^{14}$, Zeliha Selamoglu ${ }^{15} \mathbb{D}$, Miquel Martorell 16,17,*(D), \\ Farukh Sharopov ${ }^{18}\left(\mathbb{D}\right.$, Natália Martins ${ }^{19,20, *(\mathbb{D})}$, Jacek Namiesnik ${ }^{21, *}$ and William C. Cho $22, *$ (D)
}

1 Student Research Committee, School of Medicine, Bam University of Medical Sciences, Bam 44340847, Iran Zabol Medicinal Plants Research Center, Zabol University of Medical Sciences, Zabol 61615-585, Iran

3 Istanbul Technical University, Faculty of Chemical \& Metallurgical Engineering, Food Engineering Department, Maslak 34469, Istanbul, Turkey

4 Laboratoire de Biotechnologie Végétale et d'Ethnobotanique, Faculté des Sciences de la Nature et de la Vie, Université de Bejaia, Bejaia 06000, Algérie

5 Department of Plant Sciences, LCWU, Lahore 54000, Pakistan

6 G.B. Pant National Institute of Himalayan Environment \& Sustainable Development Kosi-Katarmal, Almora 263 643, Uttarakhand, India

7 G.B. Pant National Institute of Himalayan Environment \& Sustainable Development Garhwal Regional Centre, Srinagar 246174, Uttarakhand, India

8 Department of Clinical Pharmacy, University of Medicine and Pharmacy of Craiova, 200349 Craiova, Romania

9 Department of Toxicology, University of Medicine and Pharmacy of Craiova, 200349 Craiova, Romania

10 Mevsim Gida Sanayi ve Soguk Depo Ticaret A.S. (MVSM Foods), Turankoy, Kestel, Bursa 16540, Turkey

11 Institute of Fermentation Technology and Microbiology, Lodz University of Technology, Wolczanska 171/173, 90-924 Lodz, Poland

12 Molecular and Applied Mycology and Plant Pathology Laboratory, Department of Botany, University of Calcutta, Kolkata 700019, India

13 Department of Botany, Fakir Chand College, Diamond Harbour, West Bengal 743331, India

14 Department of Food Science and Technology, Nutrition and Food Sciences Faculty, Kermanshah University of Medical Sciences, Kermanshah 6719851351, Iran

15 Department of Medical Biology, Faculty of Medicine, Nigde Ömer Halisdemir University, Campus, Nigde 51240, Turkey

16 Department of Nutrition and Dietetics, Faculty of Pharmacy, University of Concepcion, Concepcion 4070386, Chile

17 Universidad de Concepción, Unidad de Desarrollo Tecnológico, UDT, Concepcion 4070386, Chile

18 Department of Pharmaceutical Technology, Avicenna Tajik State Medical University, Rudaki 139, 734003 Dushanbe, Tajikistan

19 Faculty of Medicine, University of Porto, Alameda Prof. Hernâni Monteiro, 4200-319 Porto, Portugal

20 Institute for Research and Innovation in Health (i3S), University of Porto, 4200-135 Porto, Portugal

21 Department of Analytical Chemistry, Faculty of Chemistry, Gdańsk University of Technology, 80-233 Gdańsk, Poland

22 Department of Clinical Oncology, Queen Elizabeth Hospital, Hong Kong, China

* Correspondence: javad.sharifirad@gmail.com (J.S.-R.); martorellpons@gmail.com (M.M.); ncmartins@med.up.pt (N.M.); chemanal@pg.edu.pl (J.N.); chocs@ha.org.hk (W.C.C.); Tel.: +98-21-88200104 (J.S.-R.); +56-41-266-1671 (M.M.); +351-22-5512100 (N.M.); +48-58-347-1010 (J.N.); +852-3506-6284 (W.C.C.)

Received: 25 July 2019; Accepted: 14 August 2019; Published: 16 August 2019

Abstract: The Cucurbita genus, a member of Cucurbitaceae family, also known as cucurbits, is native to the Americas. Genus members, like Cucurbita pepo and Cucurbita maxima, have been used for centuries in folk medicine for treating gastrointestinal diseases and intestinal parasites. These 
pharmacological effects are mainly attributed to their phytochemical composition. Indeed, Cucurbita species are a natural source of carotenoids, tocopherols, phenols, terpenoids, saponins, sterols, fatty acids, functional carbohydrates, and polysaccharides, that beyond exerting remarkable biological effects, have also been increasingly exploited for biotechnological applications. In this article, we specifically cover the habitat, cultivation, phytochemical composition, and food preservative abilities of Cucurbita plants.

Keywords: Cucurbita plants; cucurbits; pumpkin; phytochemical composition; food industry

\section{Introduction}

Natural products are a rich source of chemical diversity that has boosted pharmaceutical industry over the centuries [1,2]. Plants and herbs have been applied in both prevention and treatment of human disorders since ancient times [3-5]. Indeed, many investigations on herbs and plants have been conducted, and their efficacy proved as a compelling source of antioxidant, antimicrobial, anti-inflammatory [6], anticancer and neuroprotective agents [7,8].

The Cucurbitaceae (pumpkin) family contains many species as human foods. This family frames a huge gathering with roughly 130 genera and 800 species. Cucurbitaceae plants are commonly known as cucurbits, extensively cultivated in tropical and subtropical countries. Cucurbit species include pumpkins, squashes, gourds and melons [9]. In addition, it is an economically important family with a rootage of various valuable products, such as edible vegetables, fruits, seed, seed oils, and drugs. Indeed, they include a large variety of vegetables, often used through various forms for cooking, pickling, salad, dessert fruits, candied, confectionary, etc. In addition, Cucurbita products have a high nutritional value, being also an important source of vitamins, and widely used in culinary for biscuits, bread, desserts, soup and beverages production [10-12].

Overall, this article aims to provide an update on the Cucurbita plants sources, as well as historical culinary usage, habitat and cultivation, phytochemical composition and industrial purposes.

\section{Cucurbita Plants: An Historical Culinary Usage}

Cucurbita plants were first explained by Linnaeus in the middle of the eighteen century and are among the earliest known plants that have been grown by mankind. Primarily, they are classified by their shape or harvest season (summer or winter), although there are both female and male types. The male flowers produce pollen and the female ones produce the fruit. Cucurbita species have bristly and prickly stems and leaves. Broadly, leaves are large, occasionally lobed or spotted, and spiraled clinging tendrils are frequently given at the leaf axils. Both leaves and stems can be rough or prickly. Yellow or orange trumpet shaped flowers develop into variously shaped, sized, marked, and colored fruits [13]. However, these plants are also cultivated for their edible and ornamental fruit, also having therapeutic and wholesome advantages. The juvenile natural products are often expended as a vegetable, but some assortments of natural products are used with beautiful purposes in the Halloween party. They can be consumed as raw or cooked, and also for animal feed, but due to their high nutraceutical value, Cucurbita plants have been widely used in many countries as constituents of many commercial products. For instance, in Indian cuisine, squashes (ghia) are traditionally cooked with seafood, such as prawns. French people use marrows (courges) as a gratin. In Italy, many of regional dishes are prepared from squashes. Japanese people use Cucurbita moschata Duchesne pumpkins (kabocha) for preparation of different Japanese foods. C. moschata fruits can be round, oblate, oval, oblong, or pear-shaped, variously ribbed, $15-60 \mathrm{~cm}$ in diameter, and weigh up to $45 \mathrm{~kg}$. In African countries soup is prepared from squash, and soft alcoholic drinks are made from Cucurbita ficifolia Bouché. C. ficifolia fruits are oblong with a diameter of $20 \mathrm{~cm}$, weighs $5 \mathrm{~kg}$ to $6 \mathrm{~kg}$, and its skin can vary from light or dark green to cream-colored. 
Specifically, the commercially produced pumpkin is mainly used for production of pumpkin pie, bread, biscuits, cheesecake, desserts, donuts, granola, ice cream, lasagna dishes, pancakes, pudding, pumpkin butter, salads, soups, and stuffing. The seeds, wealthy in oil, likewise are used in Mexico, with nectar to make pastries, known as palanquetas. Blossom buds and blooms are used in Mexico to cook quesadillas. Indeed, Cucurbita products contain carbohydrates, protein and are also rich in vitamin C, pyridoxin (B6) and riboflavin (B2). The content of fat is negligible. Fruit and root of Cucurbita foetidissima Kunth is also rich in saponin, which can be used as soap, shampoo and bleach [10-12,14].

\section{Habitat and Cultivation of Cucurbita Plants}

\subsection{Habitat}

The Cucurbita genus is native to the Americas. Archaeological observations have explained that, for more than 8000 years, Cucurbita domestication has moved from the southern parts of Canada to Argentina and Chile [10-12,14]. Five species of the genus, namely Cucurbita argyrosperma C.Huber, C. ficifolia, C. moschata, Cucurbita maxima Duchesne, and Cucurbita pepo L. were habituated and cultivated in several areas of North and South America [15-17]. C. pepo is considered as one of the most seasoned and developed varieties, by Mexican archeological evidence of 7000 BC. Along these lines, it was extensively developed through aboriginal people through Central, North America and Mexico, earlier the landing of Europeans. C. pepo is local to Northern Mexico and Southwestern and eastern USA [18]. C. pepo fruits can be oval, cylindrical, flattened, globular, scalloped, fusiform, and/or tapering to a curved or straight neck on one or both ends. They can be up to 5 times longer than wide and their weight varies from $30 \mathrm{~g}$ to $50 \mathrm{~kg}$. The skin can be smooth, warty, wrinkled, furrowed, or/and have shallow to deep longitudinal ridges. Often there is more than one color to the soft to hard skin: white, yellow, light to dark green, nearly black, cream, and/or orange. Subsequently, Cucurbita species were cultivated in all tropical, subtropical and temperate regions of the planet and are now considered as one of the valuable foods for most of the world's inhabitants [12,19].

Cucurbita species also show diverse habitat use, growing in terrestrial and wetland environments, as monoecious climbers or annuals; they may be found in meadows, fields, and on the shores of rivers or lakes [20].

\subsection{Cultivation}

\subsubsection{Climate}

In general, Cucurbita species prefer warm weather. Temperatures of $18-27^{\circ} \mathrm{C}$ are ideal for maximum crop production. So, a long warm season is important to obtain a quality production. For seed germination, soil temperatures above $16^{\circ} \mathrm{C}$ are essential and it takes about 14 days for the crop to leaves at this temperature, and it was also reported that when soil temperature rises to $20^{\circ} \mathrm{C}$ seed emerge within a week [21]. Cucurbita species requires a continuous water supply, but overwatering also lead to crop spoiling. Uniform moisture supply is, therefore, important during the growing season of the crop. C. argyrosperma is generally cultivated in regions with little arid climate with proper watering or in regions with a distinct rainy season [22]. C. ficifolia grows in specific environmental parameters, such as not in a high frost condition, but it prefers heavy rain agricultural systems [23]. C. maxima are mainly grown in regions with temperate climate, and exceptionally grown in warm and moist area [24]. The shape of $C$. maxima fruit can be an elongated cylinder, oval, flattened, globular, heart-shaped, and/or tapering to a curved neck on one or both ends. The length (from $5.8 \mathrm{~cm}$ to $71.6 \mathrm{~cm}$ ), width (from $11.2 \mathrm{~cm}$ to $48.6 \mathrm{~cm}$ ) and weight (usually ranging from $0.3 \mathrm{~kg}$ to $50 \mathrm{~kg}$, some pumpkins can grow over $90 \mathrm{~kg}$ ) is very variable. The skin can be smooth, warty, wrinkled, or/and have shallow to deep longitudinal ridges. Often there is more than one color on the soft to hard skin: red, white, gray, black, green, cream, and/or orange. C. moschata is reported mainly from regions with low altitude, hot climate 
and high humidity $[25,26]$. C. pepo can adapt to different ecological conditions, but prefers low altitude and warm/humid places [27].

\subsubsection{Soil}

Cucurbita spp. can be grown in a wide range of soil varieties, but favors well-drained fertile ground [22]. A well-drained soil is preferred, and the crop roots can penetrate up to a meter deep into the soil. The ideal soil pH is in the range of 6.0 to 6.5 , but the crop can withstand both slightly acidic and alkaline soils. In areas with low soil $\mathrm{pH}$, the application of lime or dolomite is essential to allow better uptake of nutrients. Well-drained loamy fertile soils or sandy loam soils are good for commercial cultivation. However, heavier soils (clay) can also be used as long as drainage is adequate.

\subsubsection{Propagation and Planting Method}

Cultivated Cucurbita spp. are usually propagated by planting seeds in the ground. Sometimes, seeds are germinated in small pots and seedlings are transplanted to the field when climatic and edaphic factors are favorable [22]. Transplant seedling are often used to establish an early season crop or when using permanent beds [21]. It has been reported that Cucurbita species that are developed from transplanted seedling have luxuriant growth, larger fruit size and significantly higher seed yield compared to direct sowing method [28,29]. Commercially cultivated varieties are sometimes grown with traditional crops, like maize, beans or even in vegetable gardens along with other species. Plant density affects fruit size, yield and its number per plant. Napier [21] reported that in C. maxima and C. moschata higher plant densities resulted in smaller fruit size, higher total yield and fewer fruit per plant.

\subsubsection{Irrigation}

The first irrigation is important just after planting, and subsequent irrigation is given at a weekly basis or depending upon growth of the plant and soil condition. Waterlogging should be avoided throughout the cultivation process. However, in the absence of rain, the crop should be regularly watered. Irrigation is vital during flowering, fruit set and fruit fill, but should be minimized at the time of fruit maturity. Various types of irrigation methods are practiced in Cucurbita species cultivation, such as furrow, drip and overhead irrigation. Furrow irrigation needs the type of soil which passes water to reach laterally, without penetrating very deep into the soil, and drip irrigation is practiced in permanent bed systems which help to minimize weeds in the field [21].

\subsubsection{Fertilizer}

Proper fertilizer application is essential for Cucurbita species cultivation, but the excessive use of nitrogen fertilizer, early in the growing period, results in huge foliage growth, delayed fruit set and lower crop yield [21,30-32]. For C. maxima production, mineral fertilizers are used, which consists of NPK-nitrogen $(\mathrm{N})$, phosphorous $(\mathrm{P})$ and potassium $(\mathrm{K})$-applied either manually or with sub-soiled in a row. A nitrogen side-dressing in the form of urea, is also applied about two weeks after crop emergence [33]. In case of C. maxima, the recommended amounts of fertilizers are about $150 \mathrm{~kg}$ nitrogen/ha, $95 \mathrm{~kg}$ phosphorus/ha, $80 \mathrm{~kg}$ potassium/ha and $10 \mathrm{~kg}$ gypsum/ha [33]. Bannayan et al. [34] reported that, in C. pepo, the optimum nitrogen rate not only can increase crop growth, but can also boost up its resistance to higher temperatures.

\subsubsection{Pest and Disease Management}

Cucurbita species are very prone to pests and diseases, and some pathogens attack this economically important crop. Thus, it is important to protect them to obtain a good quality and high commercial yield Cucurbita. Several notorious fungal pathogens are associated with Cucurbita species, e.g., Cladosporium cucumerinum which causes a scab or gummosis [35], while Choanephora cucurbitarum causes fruit rot of C. pepo [36]. This disease, also known as "wet rot" and "blossom end rot", can spoil many blossoms 
and fruit during prolonged damp weather. Pseudoperonospora cubensis is an unusual organism of downy mildew Cucurbita species, mainly cucumbers, melons, squashes, gourds and watermelons [37]. Phytophthora capsici causes blight and mostly infect the seedlings, vines, leaves, and fruits of Cucurbita plants [38]. Cucurbits powdery mildew, caused by Erysiphe cichoracearum, is the most critical disease of cultivated Cucurbita spp. [39,40]. Fusarium oxysporum is a soil borne fungal pathogen that causes a damping off and wilt disorder [41]. Powdery mildew is caused by Sphaerotheca fuliginea, which forms pads of whitish mycelium on upper and under leaf sides, petioles, and stems [42]. Important bacterial diseases of Cucurbita species are across leaf spot evoked by Pseudomonas syringae pv. Lachrymans [43,44]. Bacterial wilt occurs in Cucurbita species infected with Erwinia tracheiphila. This pathogenic bacterium is imparted with striped (Acalymma vittatum) and spotted (Diabrotica undecimpunctata) cucumber beetles [45]. Several viral variants have also been identified, causing many problems to the crops due to the rate of disease expansion, asperity of infection and difficulty in controlling the diseases. The most important viral variants are clover yellow vein virus (CYVV), papaya ringspot virus Type W (PRSV), squash mosaic virus (SqMV), tobacco tingspot virus (TRSV), tomato ringspot virus (ToRSV), watermelon mosaic virus (WMV), and zucchini yellow mosaic virus (ZYMV) [22,46,47]. Many insects invade Cucurbita species, e.g., aphid species (Myzus persicae and Aphis gossypii) and beetle species (A. vittatum and D. undecimpunctata), which causes significant crop losses. Proper crop rotation is the best way to minimize pests and diseases. Thus, the application of appropriate fungicide, like copper oxychloride, bravo, cupravit, dithane, and dichlorophen, at specific doses can control fungal pathogens of Cucurbita species. However, the control of viral diseases is difficult. The breeding of disease resistant varieties by the hybridization technique or the application of innovative methods to promote resistant varieties is an additional way to control viral diseases. C. pepo cultivar contains unique transgenic forms that show resistance to viruses like WMV and ZYMV [22].

\section{Cucurbita Plants Phytochemical Composition}

Twenty-eight Cucurbita species are named in the literature [48,49], but some of them could just be hybrids or synonyms [49]. The relative lack of studies on some Cucurbita species may be linked to their rarity and endemic aspect, as is the case of Cucurbita okeechobeensis (Small) L.H.Bailey [50], also considered as an endangered species that must be protected [50,51]. The potential toxicity of the wild species may also be a limiting factor [52].

Edible kinds of pumpkins and squashes, like C. ficifolia, C. maxima, C. moschata and C. pepo can be a natural source of some bioactive components. Indeed, these species are rich in tocopherols and carotenoids, especially the seeds and the fruit peel, respectively [53]. Generally, it is complicated to make a straight qualitative or quantitative distinction between the species, because of the high variability within a single species depending either on their subsequent varieties or environmental effects and ripening stage. This aspect is also true for other phytochemicals. Depending on the edible part, Cucurbita species are found to be very rich in compounds with nutritious value, especially carbohydrates, proteins, minerals (Table 1), fatty acids (Table 2) and amino acids [53]. 
Table 1. Proximate composition of some common Cucurbita spp. *

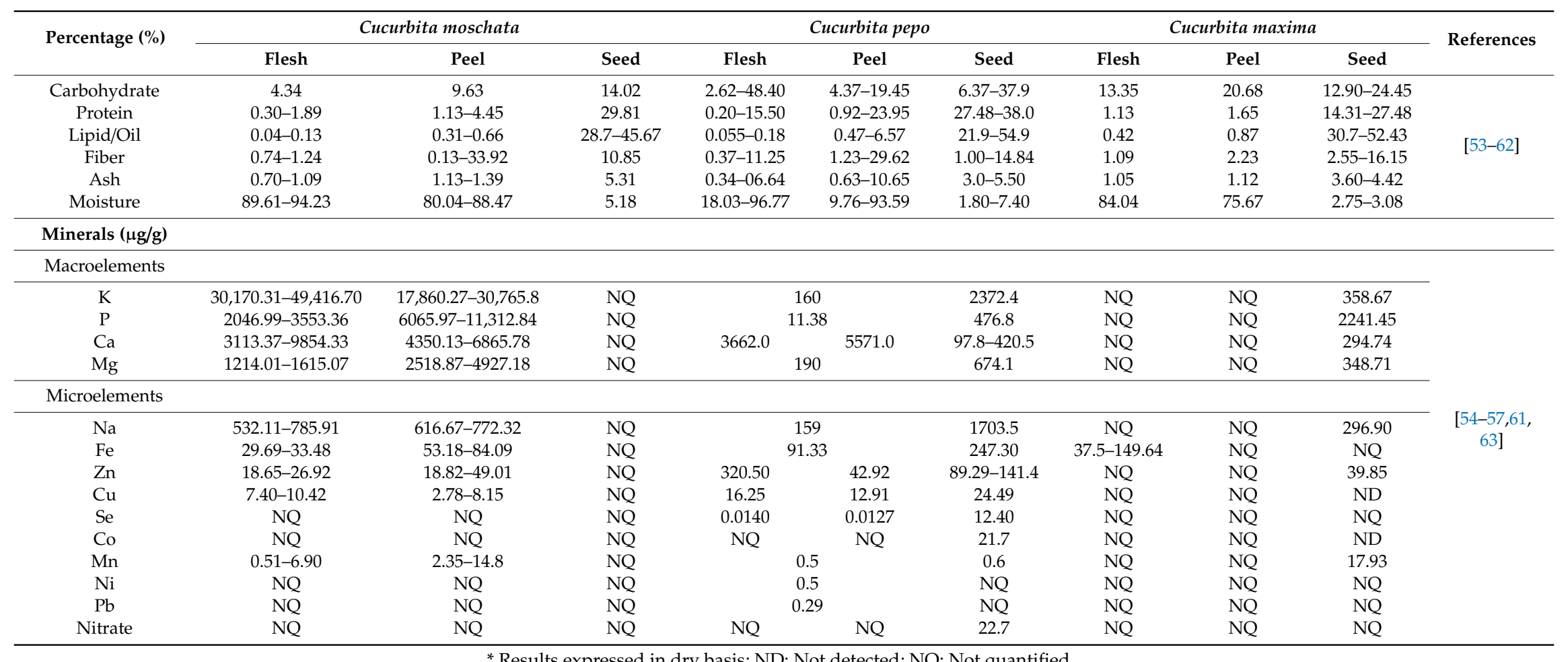

* Results expressed in dry basis; ND: Not detected; NQ: Not quantified. 
Table 2. Seed fatty acid composition of some common Cucurbita spp. *.

\begin{tabular}{ccccc}
\hline Fatty acid (\%) & Cucurbita moschata & Cucurbita pepo & Cucurbita maxima & References \\
\hline Myristic acid (C14:0) & ND & $0.1-0.23$ & 0.16 & \\
Palmitic acid (C16:0) & 12.78-20.74 & $9.5-14.5$ & $10.84-15.97$ & \\
Palmitoleic (C16:1n7) & NQ & 0.58 & NQ & \\
Heptadecanoic acid (C17:0) & ND & ND & 0.18 & \\
Stearic acid (C18:0) & $7.33-7.47$ & $03.1-8.67$ & $4.68-11.2$ & \\
Vaccenic acid (C18:1n7) & NQ & 01.8 & NQ & \\
Oleic acid (C18:1n9) & $22.66-31.34$ & $21.0-46.9$ & $14.83-44.11$ & \\
Linoleic acid (C18:2) & $35.72-48.52$ & $0.17-60.8$ & $34.77-56.60$ & {$[53,55,58-62,64]$} \\
Linolenic (C18:3) & ND & ND-0.68 & 0.24 & 0.36 \\
Arachidic acid (C20:0) & ND & 0.39 & 0.07 & \\
Gadoleic acid (C20:1n-9) & ND & $00.1-1.14$ & 0.41 & \\
Arachidonic acid (C20:4) & NQ & 00.5 & 0.09 & \\
Behenic acid (C22:00) & ND & 0.37 & $17.47-21.07$ & \\
Saturated & 20.11 & $18.69-19.35$ & $14.90-44.12$ & \\
Mono-unsaturated & 31.34 & 32.40 & $34.78-56.84$ & \\
Poly-unsaturated & 35.72 & 36.40 & $71.74-78.90$ & \\
Total unsaturated & 67.06 & $7.6-80.65$ &
\end{tabular}

* Results expressed in dry base of seeds; ND: Not detected; NQ: Not quantified.

The content of carbohydrates is highly variable within each species and edible parts, starting from $2.62 \%$ to $48.40 \%$ on dry basis. In general, the seeds and peels are richer than flesh, and C. maxima and C. pepo were described as containing higher levels of carbohydrates when compared to C. moschata. The mineral contents of Cucurbita fit the recommended daily intake values of FAO in various essential elements. In addition, it seems to be far from the upper limits [65], when the values are converted on a fresh matter basis. Seeds contain high amount of proteins and fats, ranging from $14.3 \%$ to $38.0 \%$ and $21.9 \%$ to $54.9 \%$, respectively. In contrast, fruit seems to have relatively low and variable levels of proteins $(0.20 \%$ to $23.95 \%)$, and a very low content of lipids ( $0.04 \%$ to $6.57 \%)$. Cucurbita, especially the seed parts, can also be a good source of amino acids [53]. Indeed, among the 20 amino acids which constitute the human proteins, 17 are present in Cucurbita, including the $8+1$ essential amino acids [53,55]. In addition, Fang, Li, Niu, and Tseng [66] discovered for the first time a new amino acid in C. moschata, named as cucurbitine.

\subsection{Carotenoids and Tocopherols in Cucurbita}

Carotenoids are present in high amount in the fruit of these plants and their hybrids, $\alpha$ - and $\beta$ - carotene; $\zeta$-carotene; neoxanthin; violaxanthin; lutein; zeaxanthin; taraxanthin; luteoxanthin; auroxanthine; neurosporene; flavoxanthin; 5,6,5', $6^{\prime}$-diepoxy- $\beta$-carotene; phytofluene; $\alpha$-cryptoxanthin; and $\beta$-cryptoxanthin [53,67-70]. The total carotenoid content varies in range from $234.21 \mu \mathrm{g} / \mathrm{g}$ to $404.98 \mu \mathrm{g} / \mathrm{g}$ in C. moschata fruit [71], and $171.9 \mu \mathrm{g} / \mathrm{g}$ to $461.9 \mu \mathrm{g} / \mathrm{g}$ in C. pepo fruit [61]. The concentration of carotenoids is much higher (10 fold higher) in the peel of $C$. moschata than flesh [57]. Azizah et al. [72] investigated the effect of different baking procedure on $\beta$-carotene and lycopene contents of $C$. moschata. It was observed that boiling led to a 4 and 40 -fold increase in $\beta$-carotene and lycopene contents, respectively. There are also several reports on carotenoid content of several Cucurbita plants, such as landrace pumpkins (C. moschata) [71], C. moschata and C. pepo [73,74], and C. maxima [75]. A summary of the major carotenoids found in Cucurbita species is given in Table 3. 
Table 3. Content of major carotenoid present in the edible flesh of Cucurbita spp. varieties *

\begin{tabular}{|c|c|c|c|c|c|}
\hline Cucurbita Species & Variety & $\begin{array}{l}\alpha \text {-Carotene } \\
(\mathrm{mg} / 100 \mathrm{~g})\end{array}$ & $\begin{array}{l}\beta \text {-Carotene } \\
(\mathrm{mg} / 100 \mathrm{~g})\end{array}$ & $\begin{array}{l}\text { Lutein+ Zeaxanthin } \\
\quad(\mathrm{mg} / 100 \mathrm{~g})\end{array}$ & References \\
\hline \multirow{11}{*}{ Cucurbita pepo } & Acorn Table & 0.15 & 2.1 & 1.8 & \multirow{4}{*}{ [70] } \\
\hline & Acorn Tay Bell & 0.17 & 0.94 & 0.37 & \\
\hline & $\begin{array}{l}\text { Tonda Padana } \\
\text { (Americano) }\end{array}$ & 0.12 & 2.3 & 1.5 & \\
\hline & Carneval di Venezia & 0.03 & 0.06 & ND & \\
\hline & Melonette Jaspée Vende & 0.05 & 1.3 & 0.43 & \multirow{6}{*}{ [74] } \\
\hline & Acorn Table & ND & 0.36 & 0.09 & \\
\hline & Table King Bush & ND & 0.09 & 0.02 & \\
\hline & $\begin{array}{c}\text { Thelma Sander's Sweet } \\
\text { Potato }\end{array}$ & ND & 0.06 & 0.01 & \\
\hline & Fordhook Acorn & ND & 0.04 & 0.01 & \\
\hline & PI 314806 & ND & ND & ND & \\
\hline & Sweet Lightning & NQ & 0.7 & 0.13 & [76] \\
\hline \multirow{22}{*}{ Cucurbita maxima } & Uchiki Kuri & 1.4 & 2.5 & 3 & \multirow{13}{*}{ [70] } \\
\hline & Flat White Boer & 7.5 & 6.2 & 7.5 & \\
\hline & Umber Cup & 0.79 & 3.7 & 11 & \\
\hline & Hyvita & 0.99 & 2.5 & 17 & \\
\hline & Buen Gusto & 1 & 3.3 & 6.3 & \\
\hline & Gelber Zentner & ND & 2.2 & 0.8 & \\
\hline & Mini Green Hubbard & 0.42 & 1.4 & 5.6 & \\
\hline & Autumn Cup & 0.8 & 5.2 & 2.7 & \\
\hline & Imperial Elite & 1.1 & 7.4 & 7.1 & \\
\hline & Snow Delite & 1.5 & 6.4 & 1.6 & \\
\hline & Walfish & 0.9 & 4.3 & 3.9 & \\
\hline & Japan 117 & 1 & 7.2 & 1.8 & \\
\hline & Bambino & NQ & 4.2 & NQ & \\
\hline & Amazonka & NQ & 13.1 & NQ & \multirow{4}{*}{ [77] } \\
\hline & Justynka F1 & NQ & 13.1 & NQ & \\
\hline & Karowita & NQ & 4.2 & NQ & \\
\hline & Otylia F1 & NQ & 0.6 & NQ & \\
\hline & Bischofsmütze & NQ & 0.5 & 0.03 & \multirow{5}{*}{ [76] } \\
\hline & Golden Nuggets & NQ & 1.9 & 2.6 & \\
\hline & Halloween & NQ & 0.8 & 0.87 & \\
\hline & Hokkaido I & NQ & 0.27 & 3.6 & \\
\hline & Hokkaido II & NQ & 7.1 & 6.1 & \\
\hline \multirow{12}{*}{ Cucurbita moschata } & Burpee Butterbush & 0.98 & 3.1 & 0.08 & \multirow{4}{*}{ [70] } \\
\hline & Long Island Cheese & 5.9 & 7 & 0.14 & \\
\hline & Mousquée de Provence & 2.8 & 4.9 & 1.1 & \\
\hline & Martinica & 1.6 & 5.4 & 0.41 & \\
\hline & Butterbush & 1.5 & 1.5 & 0.09 & \multirow{6}{*}{ [74] } \\
\hline & Ponca Butternut & 0.21 & 0.03 & 0.06 & \\
\hline & Waltham Butternut & 0.3 & 0.38 & 0.12 & \\
\hline & Sucrine DuBerry & 0.26 & 0.21 & 0.03 & \\
\hline & PI 458728 & 0.04 & 0.06 & 0.03 & \\
\hline & Tennessee Sweet Potato & ND & 0.2 & 0.03 & \\
\hline & Muscade de Provence & 1.1 & 0.9 & NQ & \multirow{2}{*}{ [76] } \\
\hline & Butternuts & 0.06 & 1.14 & 0.14 & \\
\hline
\end{tabular}

* Results expressed in dry base of edible flesh part; NQ: Not quantified; ND: Not detected.

Edible Cucurbita seeds are also rich in vitamin E $(49.49 \mu \mathrm{g} / \mathrm{g}$ to $92.59 \mu \mathrm{g} / \mathrm{g}) ; \gamma$-tocopherol is more abundant than $\alpha$-tocopherol $[53,62]$. The amounts of $\alpha-, \beta-, \gamma$ - and $\delta$-tocopherol from the cold pressed oil extracted from six samples of pumpkin seeds (C. pepo) from Serbia were reported by Rabrenović et al. [78], which were in the range of 38.03 to $64.11 \mathrm{mg} / 100 \mathrm{~g}$ oil. C. maxima var. béjaoui seed oil was found as a rich source of tocopherols, where $\delta$-tocopherol was the dominant tocopherol with $42 \%$ of the total [64]. However, for C. pepo seed oils, $\gamma$-tocopherol was stated as the remarkably abundant tocopherol (13-21\%) compared to $\alpha$ - and $\delta$-tocopherols [79].

\subsection{Phenolic Compounds in Cucurbita}

Table 4 presents the main phenolic compounds found in Cucurbita species and their structures. C. moschata fruit seems to have a low total phenolic content in comparison with other fruits [57]. No flavonoids were found in either the fruit nor seeds of $C$. moschata in the study of Eleiwa et al. [80]. However, Li et al. [81] have previously discovered five novel phenolic glycosides from C. moschata 
seeds, named cucurbitosides A-E. Other new phenolic glycosides were discovered later from the same source $[81,82]$. In another work, Li et al. [83] isolated eight different cucurbitoside compounds (F-M).

Table 4. Chemical structures of phenolic compounds found in the Cucurbita spp. *

\begin{tabular}{|c|c|c|c|}
\hline Compound Name & Synonym(s) & $\begin{array}{c}\text { Empirical } \\
\text { Formula }\end{array}$ & Structure \\
\hline Protocatechuic acid & 3,4-Dihydroxybenzoic acid & $\mathrm{C}_{7} \mathrm{H}_{6} \mathrm{O}_{4}$ & \\
\hline p-Hydroxybenzoic acid & 4-Hydroxybenzoic acid & $\mathrm{C}_{7} \mathrm{H}_{6} \mathrm{O}_{3}$ & \\
\hline p-Hydroxybenzaldehyde & 4-Hydroxybenzaldehyde & $\mathrm{C}_{7} \mathrm{H}_{6} \mathrm{O}_{2}$ & \\
\hline Vanillic acid & $\begin{array}{l}\text { 4-Hydroxy-3-methoxybenzoic acid; } \\
\text { p-Vanillic acid }\end{array}$ & $\mathrm{C}_{8} \mathrm{H}_{8} \mathrm{O}_{4}$ & \\
\hline Caffeic acid & 3,4-Dihydroxycinnamic acid & $\mathrm{C}_{9} \mathrm{H}_{8} \mathrm{O}_{4}$ & \\
\hline Syringic acid & 3,5-Dimethoxy-4-hydroxybenzoic acid & $\mathrm{C}_{9} \mathrm{H}_{10} \mathrm{O}_{5}$ & \\
\hline Trans-p-coumaric acid & trans-4-Hydroxycinnamic acid & $\mathrm{C}_{9} \mathrm{H}_{8} \mathrm{O}_{3}$ & \\
\hline Ferulic acid & $\begin{array}{c}\text { 3-Methoxy-4-Hydroxycinnamic acid; } \\
\text { 3-Methylcaffeic acid; } \\
\text { Coniferic acid }\end{array}$ & $\mathrm{C}_{10} \mathrm{H}_{10} \mathrm{O}_{4}$ & \\
\hline
\end{tabular}


Table 4. Cont.

\begin{tabular}{|c|c|c|c|}
\hline Compound Name & Synonym(s) & $\begin{array}{l}\text { Empirical } \\
\text { Formula }\end{array}$ & Structure \\
\hline Trans-sinapic acid & $\begin{array}{l}\text { trans-4-Hydroxy-3,5-dimethoxy-cinnamic acid; } \\
\text { trans-Sinapinic acid }\end{array}$ & $\mathrm{C}_{11} \mathrm{H}_{12} \mathrm{O}_{5}$ & \\
\hline Tyrosol & $\begin{array}{l}\text { p-HPEA; 4-(2-Hydroxyethyl)phenol; } \\
\text { 2-(4-Hydroxyphenyl)ethanol; } \\
\text { 2,4-Hydroxyphenyl-ethyl-alcohol; } \\
\text { 4-Hydroxyphenylethanol }\end{array}$ & $\mathrm{C}_{8} \mathrm{H}_{10} \mathrm{O}_{2}$ & \\
\hline Vanillin & $\begin{array}{l}\text { 4-Hydroxy-3-methoxy-benzoic aldehyde; } \\
\text { Methylprotocatechuic aldehyde; } \\
\text { Vanillic aldehyde; p-Vanillin }\end{array}$ & $\mathrm{C}_{8} \mathrm{H}_{8} \mathrm{O}_{3}$ & \\
\hline Luteolin & $5,7,3^{\prime}, 4^{\prime}$-Tetrahydroxyflavone & $\mathrm{C}_{15} \mathrm{H}_{10} \mathrm{O}_{6}$ & \\
\hline Kaempferol & $3,5,7,4^{\prime}$-Tetrahydroxyflavone & $\mathrm{C}_{15} \mathrm{H}_{10} \mathrm{O}_{6}$ & \\
\hline
\end{tabular}

* The data were collected from the Phenol-Explorer database which is an online comprehensive database on polyphenol contents in foods, http://phenol-explorer.eu/ (Accessed on 09.12.2018).

A study by Yang et al. [84] showed no flavonoid content (detection limit: $0.05 \mathrm{mg} / 100 \mathrm{~g}$ ) in either the immature or mature fruits of $C$. maxima. Only the shoots and buds showed positive results. However, in accordance with [85], the total flavonoid and phenolic contents of this species were determined as approximately $2.7 \mathrm{mg}$ quercetin equivalent/g extract and $8.8 \mathrm{mg}$ gallic acid equivalent (GAE)/g extract, respectively. Sreeramulu and Raghunath [86] reported that average total phenolic content of C. maxima was $46.43 \mathrm{mg}$ GAE/100 g. In another study, C. maxima was analyzed for its flavonoid content, and kaempferol was found to be the only flavonoid present in this species at a concentration of $371.0 \mathrm{mg} / \mathrm{kg}$ of dry weight [87].

C. pepo was also found to have low polyphenol content. However, Iswaldi et al. [88] have reported for the first time a list of 34 polyphenols, including a variety of flavonoids in the C. pepo fruit, in addition to other unknown polar compounds. Also, the C. pepo flowers may contain considerable amounts of phenolic compounds. A total polyphenol content ranging from 0.054 to $0.297 \mu \mathrm{g} \mathrm{GAE} / \mu \mathrm{g}$ dry biomass has been reported to be dependent on the extraction conditions and flower sex [89]. Andjelkovic et al. [90] studied the phenolic content of six pumpkin (С. pepo) seed oils and identified the following compounds: tyrosol, luteolin, ferulic acid, vanillic acid, and vanillin. Among them, tyrosol was the most abundant compound, ranging from $1.58 \mathrm{mg} / \mathrm{kg}$ to $17.69 \mathrm{mg} / \mathrm{kg}$.

Five major compounds in C. ficifolia fruit aqueous extract were identified by Jessica et al. [91] as: $p$-coumaric acid, $p$-hydroxybenzoic acid, salicin, stigmast-7,2,2-dien-3-ol and stigmast-7-en-3-ol. On the other hand, Peričin et al. [92] assessed the phenolic acids content of C. pepo seeds. $p$-Hydroxybenzoic acid was found to be the prevailing phenolic acid, with $34.72 \%, 51.80 \%$, and $67.38 \%$ of the total phenolic acids content in whole dehulled seed, hulls, and kernels, respectively. Aside from $p$-hydroxybenzoic acid, the most dominant phenolic substances can be listed in a decreasing order of quantity as 
follows: caffeic, ferulic, and vanillic acids in whole dehulled seeds. Trans-sinapic and protocatechuic acids, and $p$-hydroxybenzaldehyde were the abundant phenolic acids presented in kernels of hulled pumpkin variety; the hulls comprised $p$-hydroxybenzaldehyde, vanillic, and protocatechuic acids with considerable amounts.

\subsection{Terpenoids, Saponins and Sterols in Cucurbita}

Badr et al. [55] have demonstrated the existence of calotropoleanly ester and cholesterol in C. pepo fruit, and Younis et al. [62] also represented the cholesterol content in seeds ( $<0.2$ to $3 \mathrm{mg} / 100 \mathrm{~g}$ ). These plant parts were also reported as containing more $\beta$-sitosterol $(383.89 \mathrm{mg} / \mathrm{kg}$ fresh weight) than those of C. moschata and C. maxima (277.58 mg/kg and $235.16 \mathrm{mg} / \mathrm{kg}$ fresh weight, respectively) [53]. Dubois et al. [93] have reported that, besides cucurbitacins, a new triterpenoid saponin, foetidissimoside $\mathrm{A}$ (3,28-bidesmosidic triterpenoid saponin) is also present in C. foetidissima roots. Ten years later, Gaidi et al. [94] discovered the foetidissimoside B in the same source. Also, Matus et al. [95] extracted sterols from seeds, and the most abundant were $\Delta 7.22 .25$-stigmastatrienol, $\beta$-sitosterol, spinasterol and $\Delta 7.25$-stigmastadienol [61].

Cucurbitacin is a triterpenoid [96] with a bitter taste, isolated from members of the Cucurbitaceae family, and there are more than 18 types of cucurbitacin in the nature. Cucurbitacins are a group of distinctive highly oxygenated triterpenoid substances, having tetracyclic triterpenes with a cucurbitane skeleton. Figure 1 details the structure of $19-(10 \rightarrow 9 \beta)$-abeo-10 $\alpha$-lanost-5-ene. They are cucurbitane triterpenes with double bonds between C4 and C5, a hydroxyl at C16, C20 and C25 and a ketone at C11 and C22 [20]. These compounds are well-recognized for their bitterness and toxicity [97].

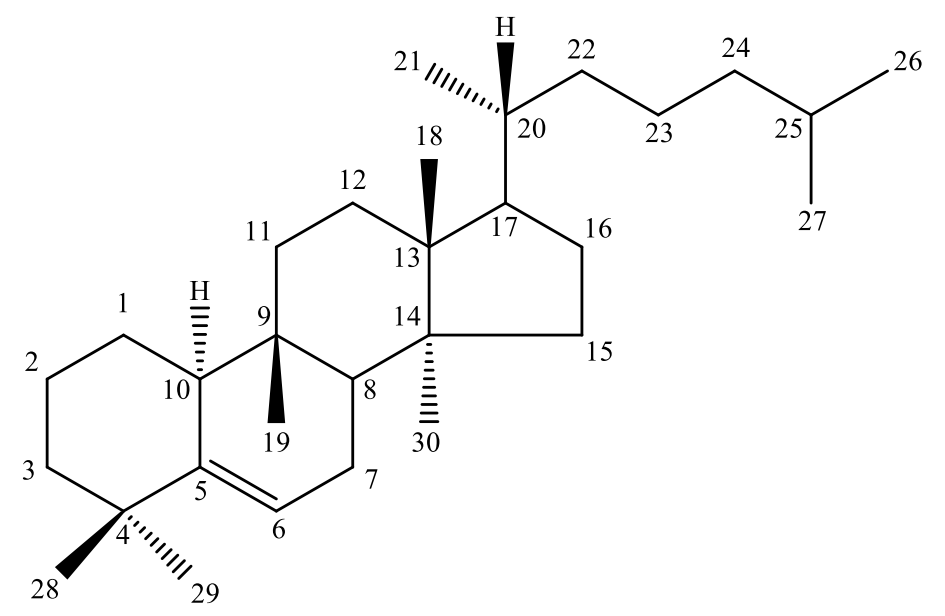

Figure 1. Principal structure of cucurbitacins $(19-(10 \rightarrow 9 \beta)$-abeo-10 $\alpha$-lanost-5-ene).

Cucurbitacins are randomly divided into 12 groups, specifically cucurbitacins $\mathrm{A}-\mathrm{T}$, varying in their oxygen functionalities at different positions. The chemical structures of a few cucurbitacins (A, B, $\mathrm{C}$, and D) are presented in Figure 2, and the cucurbitacin composition in different Cucurbita species is summarized in Table 5. 


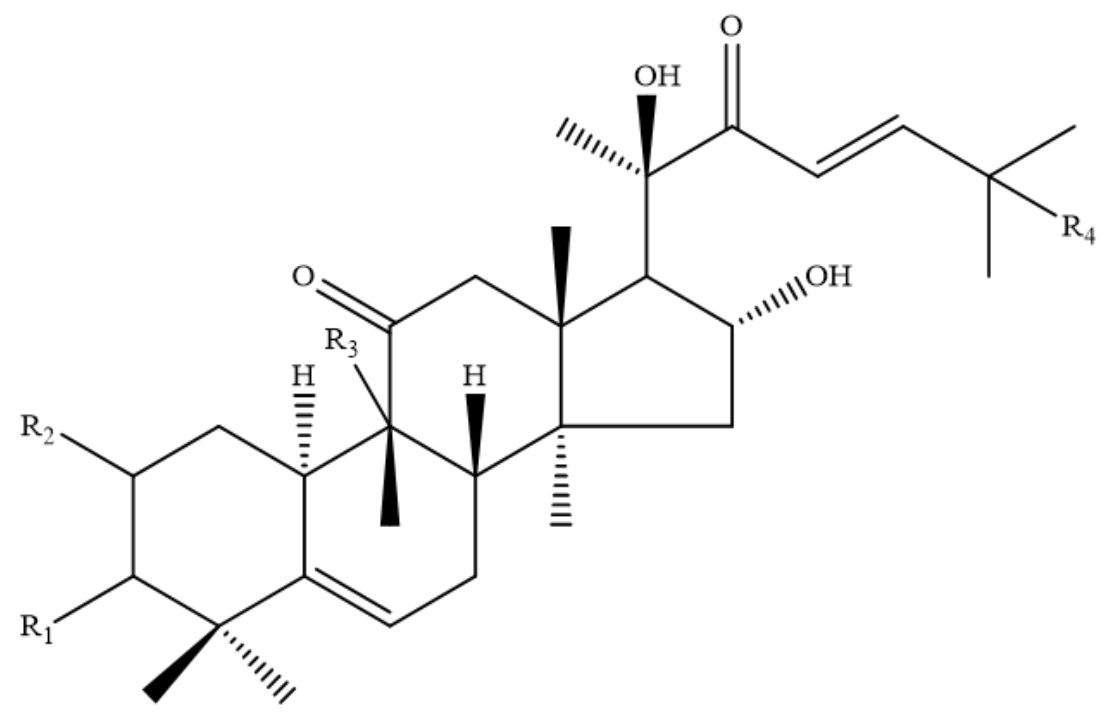
(a) $\mathrm{R}_{1}:=\mathrm{O}$
$\mathrm{R}_{2}: \mathrm{OH}$
$\mathrm{R}_{3}: \mathrm{CH}_{2} \mathrm{OH}$
$\mathrm{R}_{4}: \mathrm{OCOCH}_{3}$
(b) $\mathrm{R}_{1}:=\mathrm{O}$
$\mathrm{R}_{2}: \mathrm{OH}$
$\mathrm{R}_{3}: \mathrm{H}$
$\mathrm{R}_{4}: \mathrm{OCOCH}_{3}$
(c) $\mathrm{R}_{1}: \mathrm{OH}$
$\mathrm{R}_{2}: \mathrm{H}$
$\mathrm{R}_{3}: \mathrm{CH}_{2} \mathrm{OH}$
$\mathrm{R}_{4}: \mathrm{OCOCH}_{3}$
(d) $\mathrm{R}_{1}:=\mathrm{O}$
$\mathrm{R}_{2}: \mathrm{OH}$
$\mathrm{R}_{3}: \mathrm{H}$
$\mathrm{R}_{4}: \mathrm{OH}$

Figure 2. Structure of different cucurbitacin: (a) Cucurbitacin A, (b) Cucurbitacin B, (c) Cucurbitacin C and (d) Cucurbitacin D.

Table 5. Cucurbitacin content of Cucurbita spp. (mg/g fresh weight) *.

\begin{tabular}{|c|c|c|c|c|c|c|}
\hline Species & Plant Part & B & $\mathbf{D}$ & $\mathbf{E}$ & $\mathbf{I}$ & References \\
\hline \multirow{3}{*}{ Cucurbita maxima } & Radicles & $0.1-1$ & $\operatorname{Tr}$ & $0.01-0.1$ & ND & \multirow{3}{*}{$\begin{array}{l}{[98]} \\
{[48]}\end{array}$} \\
\hline & Cotyledons & $0.1-1$ & $0.01-0.1$ & $0.01-0.1$ & ND & \\
\hline & Leaf, fruit, root & $<0.02$ & $<0.02$ & $<0.02$ & $<0.02$ & \\
\hline \multirow{3}{*}{ Cucurbita andreana } & Leaf & 0.15 & 0.12 & ND & ND & \multirow{3}{*}{ [48] } \\
\hline & Fruit & 2.78 & 0.42 & ND & ND & \\
\hline & Root & 0.58 & 0.51 & ND & ND & \\
\hline Cucurbita. andreana $\times$ C. maxima & Fruit & 1.17 & 0.09 & ND & ND & [99] \\
\hline Cucurbita mixta Pang. & Cotyledons & $0.01-0.1$ & $\mathrm{ND}$ & ND & $\mathrm{ND}$ & [98] \\
\hline \multirow{7}{*}{ Cucurbita pepo } & Radicles & $\operatorname{Tr}$ & ND & $0.1-1$ & $\operatorname{Tr}$ & \multirow{2}{*}{ [98] } \\
\hline & Cotyledons & $0.1-1$ & $0.01-0.1$ & $0.01-0.1$ & ND & \\
\hline & Fruits & ND & ND & 3.1 & ND & \multirow{3}{*}{ [52] } \\
\hline & Flesh at the stem end & ND & ND & 7.2 & ND & \\
\hline & Fruit-central portion & ND & ND & 2.7 & ND & \\
\hline & Fruit & ND & ND & 0.6 & ND & [100] \\
\hline & Fruit & ND & ND & 1.12 & ND & [101] \\
\hline \multirow{3}{*}{ Cucurbita texana Gray } & Leaf & ND & ND & $\operatorname{Tr}$ & $\operatorname{Tr}$ & \multirow{3}{*}{ [48] } \\
\hline & Fruit & ND & ND & 0.07 & 0.367 & \\
\hline & Root & ND & ND & 0.18 & 0.08 & \\
\hline Cucurbita texana $\times$ C. pepo & Fruit & ND & ND & 0.23 & 0.09 & [99] \\
\hline \multirow{3}{*}{ Cucurbita martinezii Bailey } & Leaf & ND & ND & 0.42 & 0.25 & \multirow{3}{*}[48]{} \\
\hline & Fruit & ND & ND & 0.36 & 0.45 & \\
\hline & Root & ND & ND & 0.23 & 0.65 & \\
\hline \multirow{3}{*}{ Cucurbita lundelliana Bailey } & Leaf & 0.47 & 0.12 & ND & ND & \multirow{3}{*}[48]{} \\
\hline & Fruit & 0.63 & 0.15 & ND & ND & \\
\hline & Root & 0.53 & 0.29 & ND & ND & \\
\hline Cucurbita foetidissima & Root & ND & ND & 0.28 & 1.72 & [99] \\
\hline
\end{tabular}


Seedlings of the pumpkin C. maxima have been reported to involve high amounts of cucurbitacin $\mathrm{B}$ and small amounts of cucurbitacin D and $\mathrm{E}$ in radicles and cotyledons [98]. Eighteen Cucurbita plants species were analyzed for their cucurbitacin contents. Bitter species having comparatively high contents of cucurbitacins B and D and no detectable cucurbitacins E and I were identified as Cucurbita andreana Naudin, Cucurbita ecuadorensis Cutler \& Whitaker, Cucurbita radicans Naudin, Cucurbita lundelliana L.H.Bailey, C. argyrosperma and Cucurbita pedatifolia L.H.Bailey. The other group of wild, bitter species having relatively large amounts of cucurbitacins E and I were Cucurbita cylindrata L.H.Bailey, C. foetidissima, C. martinezii, C. okeechobeensis, and Cucurbita palmata S.Watson, Cucurbita pepo var. texana (Scheele) D.S.Decker was found to contain nearly all cucurbitacins as cucurbitacin E-glycoside. However, no cucurbitacin could be identified in domesticated and sweet species, including C. ficifolia, C. maxima, C. moschata, and C. pepo [48]. The same group of investigators also determined the cucurbitacin and cucurbitacin glycoside content in fruits of two Cucurbita plant hybrids (C. andreana $\times$ C. maxima and C. texana $\times$ C. pepo), as well as in C. foetidissima roots. As a result, C. andreana $\times$ C. maxima fruits contained cucurbitacins B and D, whereas $C$. texana $\times$ C. pepo fruits and $C$. foetidissima roots presented cucurbitacins E and I [99]. With regards to $C$. andreana fruits extract, it was chromatographically fractionated, and cucurbitacins B, D, E and I, as well as cucurbitacin E and I aglycones and cucurbitacin $\mathrm{B}, \mathrm{E}$, and I glucosides were detected in this species [102]. C. pepo comprises the most investigated Cucurbita plant for its cucurbitacin content. In an earlier study, cucurbitacin E was detected as a primary bitter component in seedling C. pepo radicles, whereas cucurbitacins B and I were found in trace amounts in the same tissue. On the other hand, cotyledons of this species were found to include cucurbitacin D and E in moderate and low concentrations, respectively [103]. Freeze-dried samples of Blackjack cultivar of C. pepo were analyzed by two research teams in different years. Ferguson et al. [101] found $1.12 \mathrm{mg}$ cucurbitacin E-glycoside/g fresh weight, whereas Hutt and Herrington [100] detected $0.6 \mathrm{mg}$ cucurbitacin E-glycoside/g fresh weight. Wang et al. [104] investigated C. pepo cv dayangua for its phytochemical content, and cucurbitacin $\mathrm{L}$ and cucurbitacin $\mathrm{K}$ were isolated at concentrations of $2.13 \mathrm{mg} / \mathrm{kg}$ dry matter and $2.67 \mathrm{mg} / \mathrm{kg}$ dry matter, respectively. In a very recent study, cucurbitacin $C$ and $E$ glycosides in C. pepo fruit were reported for the first time. The corresponding concentrations of compounds were $105 \mu \mathrm{g} / \mathrm{g}$ fresh fruit for cucurbitacin $\mathrm{C}$ and $438 \mu \mathrm{g} / \mathrm{g}$ fresh fruit cucurbitacin $\mathrm{E}$. The authors also demonstrated that gamma irradiation did not affect the cucurbitacins concentration, when compared to non-irradiated control group [105].

From a biological point of view, it has been demonstrated that cucurbitacins exert several bioactivities, such as antitumor, anti-inflammatory, anti-atherosclerotic, antidiabetic effects [106]. There is a large body of evidence suggesting that cucurbitacins hold very high orders of cytotoxicity towards a vast quantity of malignancies. Seed and fruit portions of few cucurbits are found to exhibit purgative, emetic and anthelmintic activities due to presence of cucurbitacin triterpenoids $[107,108]$. Jayaprakasam et al.[109] isolated cucurbitacins B, D, E, and I from C. andreana fruits and evaluated their effects at a level of growth suppression of human breast (MCF-7), colon (HCT-116), lung (NCI-H460), and central nervous system (CNS) (SF-268) tumor cell lines; cyclooxygenase-1 (COX-1) and cyclooxygenase-2 (COX-2) enzymes; and even on lipid peroxidation. All isolated cucurbitacins were able to abate the proliferation of investigated cancer cell lines in varying percentages. Among them, cucurbitacin B exhibited more than $80 \%$ proliferation inhibitory activity. Additionally, cucurbitacins B, D, E, and I inhibited COX-2 enzyme, an enzyme responsible for inflammation, by $32 \%, 29 \%, 35 \%$, and $27 \%$, respectively, at a concentration of $100 \mathrm{mg} / \mathrm{mL}$. A cucurbitacin derivative, with a cucurbitacin D-like structure, was separated from the methanolic extract of $C$. pepo seeds and revealed to have antiulcer activity in a dose-dependent manner [110].

In contrast to their biological activities, cucurbitacins have toxic effects in mammalians. According to Le Roux et al. [111], 353 poisoning cases linked to C. pepo cucurbitacins were reported to French Poison Control Centers between 1 January 2012 and 12 December 2016. In 1980s, various human poisoning cases were stated due to the consumption of commercially produced zucchini (C. pepo) in Australia. The most common developed characteristic symptoms evidenced by exposed individuals 
include a bitter taste in the mouth, abdominal pain, diarrhea and rarely, collapse [101]. Pfab et al. [112] reported that, 81 symptomatic cases were registered to Poison Information Centre (PIC) Munich between 2002 to 2015. The primary symptom was colitis with bloody diarrhea after zucchini (C. pepo) consumption. As the authors stated, cucurbitacins, the responsible toxins of poisonings, are not often identified in cultivated fruits, but some fruits spontaneously produced them. In an in vivo experiment, mice were fed with C. pepo fruit of two cultivars, 'Blackjack' and 'Straightneck', and an accession of the bitter species, C. texana. As a result, mice having the diet with $1 \%$. texana, containing cucurbitacins $\mathrm{E}$ glycoside and I, exhibited poor growth, severe diarrhea, anemia and $40 \%$ mortality. When the $C$. texana percentage increased to 10 or $20 \%$, mortality rate reached $100 \%$ within a few days. However, no detectable cucurbitacins in C. pepo cultivars were identified and, animals fed up to $20 \%$ freeze-dried squash in their diets displayed no toxicity-related symptoms [113].

\subsection{Functional Carbohydrates and Polysaccharides in Cucurbita}

C. moschata fruit is a rich source of polysaccharides, with a useful biological benefit, i.e., cytoprotective and antioxidative activities [114,115], that can reach $16.2 \%$ in dry matter, under optimised conditions [116]. Xia and Wang [117] reported high amounts of D-chiro-inositol, a hypoglycaemic molecule, in C. ficifolia fruit (without seeds). In addition to D-chiro-inositol, the plant was found to be rich in other carbohydrates, like myo-inositol, fagopyritols and sucrose [117].

\subsection{Fatty Acids of the Oil of Cucurbita Seeds}

Seeds of Cucurbita species are also rich in fat (around $45 \%$ ) and a variety of fatty acids, such as saturated, unsaturated (around $55 \%$ of the oil), and conjugated fatty acids (CFA) [118,119], therefore, may be considered as a source of molecules with high pharmacological potential and health benefits. Specifically, CFA are polyunsaturated fatty acids containing conjugated double bonds with positional and geometric isomers, and have several beneficial effects [120].

\subsection{Other}

C. ficifolia can also be considered a safe source of proteinases, with a high potential to be used for bioactive peptides production [121,122]. Other enzymes, like peroxidases can be obtained from C. moschata [123]. No alkaloids were found in neither the fruit nor seeds of C. moschata [80]. In contrast, Chonoko and Rufai [124] have represented alkaloid contents both in the back peels and seeds of C. pepo. Elinge et al. [56] also reported the presence of phytate $(35.06 \mathrm{mg} / 100 \mathrm{~g})$, oxalate $(0.02 \mathrm{mg} / 100 \mathrm{~g})$, hydrocyanic acid $(0.22 \mathrm{mg} / 100 \mathrm{~g})$ and nitrate $(2.27 \mathrm{mg} / 100 \mathrm{~g})$ as antinutrient compounds in C. pepo seeds.

\section{Cucurbita Plants for Industrial Purposes: Key Role as a Food Preservative}

Three main pumpkin varieties, including C. pepo, C. maxima, and C. moschata, are considered both as nutritional and medicinal foods in many countries [125]. Some biological activities are reported in pumpkins, among them antimicrobial activity $[126,127]$. The reason why this plant show antimicrobial applications is related to its high vitamins content (mainly A and C), phenolic compounds, minerals, dietary fiber, amino acids and other advantageous compounds to humans. Indeed, antioxidant, antibacterial and intestinal antiparasitic activities are also part of the active function of this crop [125,128]. Pumpkin extracts are rich in steroids, flavonoids, tannins, alkaloids and saponins, showing momentous antimicrobial and antifungal activity against some microorganisms [124,129]. Based on Muruganantham et al. [130] study, the ethyl acetate extract of C. maxima flowers has meaningful antifungal and antibacterial activity against some microorganisms, like Escherichia coli, Salmonella typhi, Bacillus cereus, Enterobacter faecalis, Candida albicans, and Curvularia lunata. Nonetheless, the antioxidant and antimicrobial effects of pumpkin seeds have also been reported. The extracted oil from pumpkin seeds chiefly contains fatty acids, among them linoleic, oleic, palmitic and stearic acids. In addition, the oil is also full of tocopherols ( $\delta$-tocopherol, $\gamma$-tocopherol, $\beta$-tocopherol and carotenoids, like lutein and $\beta$-carotene), characterized by displaying strong antioxidant effects. It is 
worth noting that pumpkin seeds oil can preserve lipids by having selenium, tocopherol, enzymes, hormones and vitamins. Adeel et al. [126] stated that pumpkin seed oil exhibits high antibacterial activity against Staphylococcus aureus, and pumpkin seeds are also able to markedly inhibit Rhodotorula rubra and C. albicans growth at $0.5 \mathrm{mg} / \mathrm{mL}$ and $1.0 \mathrm{mg} / \mathrm{mL}$, respectively [129]. Other research showed that Bacillus subtilis, S. aureus, E. coli and Klebsiella pneumonia are easily affected by the antibacterial properties of the methanolic extract from seed oil at $1.0 \mathrm{mg} / \mathrm{mL}, 2.0 \mathrm{mg} / \mathrm{mL}, 2.0 \mathrm{mg} / \mathrm{mL}$ and $3.0 \mathrm{mg} / \mathrm{mL}$, respectively [127]. Moreover, the authors stated that the antibacterial activity is not the only property of the oil, since it also exerts a remarkable antifungal activity against $R$. rubra and $C$. albicans, at concentrations of $0.5 \mathrm{mg} / \mathrm{mL}$ and $1.0 \mathrm{mg} / \mathrm{mL}$, respectively. It has even been stated that there is a high susceptibility of R. rubra to the seeds' oil. Still, researchers have stressed that $1.0 \mathrm{mg} / \mathrm{mL}$ of pumpkin oil seeds was effective against Penicillium chrysogenum and Aspergillus parasiticus, and $2.0 \mathrm{mg} / \mathrm{mL}$ against A. flavus [127].

Pumpkin rinds and leaves contain some special bioactive proteins, which have shown preservative effects. For example, pumpkin leaves contain the PR-5 antifungal protein [131], highly homologous to thaumatin. In addition, the antimicrobial activity of this protein, besides the synergistic effect of nikkomycin against $C$. albicans development, has been proved. Moreover, the growth and survival of the phytopathogenic bacteria Erwinia amylovora, Phytophthora infestans and Pseudomonas solanacearum is prohibited by a ribosome-inactivating protein purified from C. moschata [132]. Black pumpkin seeds have another component, named cucurmoschin and identified as an antifungal peptide abundant in glycine, arginine, and glutamate residues. Additionally, Park and et al. [133] found two novel antifungal proteins (Pr-1 and $\mathrm{Pr}-2$ ) from pumpkin rinds that showed strong in vitro antifungal activity against Botrytis cinerea, Colletotrichum coccodes, Fusarium solani, F. oxysporum, and Trichoderma harzianum at $10-20 \mu \mathrm{M}$.

\section{Conclusions and Future Perspectives}

Overall, Cucurbita species have chemical components with an intriguing impact in health promotion. Several squash and pumpkin species are a natural and rich source of potential bioactive compounds, such as carotenoids, tocopherols, phenols, terpenoids, saponins, sterols, fatty acids, functional carbohydrates and polysaccharides. Of these triterpenoids, cucurbitacins are particularly noteworthy for their multiple marked abilities. The presence of active phytochemicals in Cucurbitaceae species makes them a great matrix to be further exploited for both preventive and therapeutic purposes, beyond biotechnological applications. For an emphasis on Cucurbita plants' pharmacological potential, please refer to other review [134].

Author Contributions: All authors contributed significantly to this work. In addition, J.S.-R., M.M., N.M., W.C.C., and J.N., critically reviewed the manuscript. All the authors read and approved the final manuscript.

Funding: This research received no external funding.

Acknowledgments: This work was supported by CONICYT PIA/APOYO CCTE AFB170007. N. Martins would like to thank the Portuguese Foundation for Science and Technology (FCT-Portugal) for the Strategic project ref. UID/BIM/04293/2013 and "NORTE2020-Northern Regional Operational Program" (NORTE-01-0145-FEDER-000012).

Conflicts of Interest: The authors declare no conflict of interest.

\section{References}

1. Sharifi-Rad, M.; Nazaruk, J.; Polito, L.; Morais-Braga, M.F.B.; Rocha, J.E.; Coutinho, H.D.M.; Salehi, B.; Tabanelli, G.; Montanari, C.; Contreras, M.D.M.; et al. Matricaria genus as a source of antimicrobial agents: From farm to pharmacy and food applications. Microbiol. Res. 2018, 215, 76-88. [CrossRef] [PubMed]

2. Sharifi-Rad, J.; Sharifi-Rad, M.; Salehi, B.; Iriti, M.; Roointan, A.; Mnayer, D.; Soltani-Nejad, A.; Afshari, A. In vitro and in vivo assessment of free radical scavenging and antioxidant activities of Veronica persica Poir. Cell. Mol. Biol. 2018, 64, 57-64. [CrossRef] [PubMed] 
3. Mishra, A.P.; Saklani, S.; Salehi, B.; Parcha, V.; Sharifi-Rad, M.; Milella, L.; Iriti, M.; Sharifi-Rad, J.; Srivastava, M. Satyrium nepalense, a high altitude medicinal orchid of Indian Himalayan region: Chemical profile and biological activities of tuber extracts. Cell. Mol. Biol. 2018, 64, 35-43. [CrossRef] [PubMed]

4. Mishra, A.P.; Sharifi-Rad, M.; Shariati, M.A.; Mabkhot, Y.N.; Al-Showiman, S.S.; Rauf, A.; Salehi, B.; Župunski, M.; Sharifi-Rad, M.; Gusain, P.; et al. Bioactive compounds and health benefits of edible Rumex species-A review. Cell. Mol. Biol. 2018, 64, 27-34. [CrossRef]

5. Sharifi-Rad, M.; Fokou, P.V.T.; Sharopov, F.; Martorell, M.; Ademiluyi, A.O.; Rajkovic, J.; Salehi, B.; Martins, N.; Iriti, M.; Sharifi-Rad, J. Antiulcer Agents: From Plant Extracts to Phytochemicals in Healing Promotion. Molecules 2018, 23, 1751. [CrossRef]

6. Denev, P.; Kratchanova, M.; Ciz, M.; Lojek, A.; Vasicek, O.; Blazheva, D.; Nedelcheva, P.; Vojtek, L.; Hyrsl, P. Antioxidant, antimicrobial and neutrophil-modulating activities of herb extracts. Acta Biochim. Pol. 2014, 61, 359-367. [CrossRef]

7. Selamoglu, Z. The natural products and healthy life. J. Tradit. Med. Clin. Naturop. 2018, 7, e146.

8. Selamoğlu, Z. Polyphenolic Compounds in Human Health with Pharmacological Properties. J. Tradit. Med. Clin. Naturop. 2017, 6, e138. [CrossRef]

9. Shah, B.N.; Seth, A.K.; Desai, R.V. Phytophannacological profile of lagenaria siceraria, a review. Asian J. Plant Sci. 2010, 9, 152-157.

10. Andolfo, G.; Di Donato, A.; Darrudi, R.; Errico, A.; Cigliano, R.A.; Ercolano, M.R. Draft of zucchini (Cucurbita pepo L.) proteome: A resource for genetic and genomic studies. Front. Genet. 2017, 8. [CrossRef]

11. Dubey, S.D.; Dubey, S.D. Overview on Cucurbita maxima. Int. J. Phytopharm. 2012, 2. [CrossRef]

12. Paris, H.S. Historical records, origins, and development of the edible cultivar groups of Cucurbita pepo (Cucurbitaceae). Econ. Bot. 1989, 43, 423-443. [CrossRef]

13. Neelamma, G.; Swamy, B.D.; Dhamodaran, P. Phytochemical and pharmacological overview of Cucurbita maxima and future perspective as potential phytotherapeutic agent. Eur. J. Pharm. Med. Res. 2016, 3, $277-287$.

14. Adnan, M.; Gul, S.; Batool, S.; Fatima, B.; Rehman, A.; Yaqoob, S.; Shabir, H.; Yousaf, T.; Mussarat, S.; Ali, N.; et al. A review on the ethnobotany, phytochemistry, pharmacology and nutritional composition of Cucurbita pepo L. J. Phytopharm. 2017, 6, 133-139.

15. Jeffrey, C. Systematics of the cucurbitaceae: An overview. In Biology and Utilization of the Cucurbitaceae; Bates, D.M., Robinson, R.W., Jeffrey, C., Eds.; Cornell University Press: Ithaca, NY, USA, 1990; pp. 449-463.

16. Sanjur, O.I.; Piperno, D.R.; Andres, T.C.; Wessel-Beaver, L. Phylogenetic relationships among domesticated and wild species of Cucurbita (Cucurbitaceae) inferred from a mitochondrial gene: Implications for crop plant evolution and areas of origin. Proc. Natl. Acad. Sci. USA 2002, 99, 535-540. [CrossRef] [PubMed]

17. Smith, B.D. Documenting plant domestication: The consilience of biological and archaeological approaches. Proc. Natl. Acad. Sci. USA 2001, 98, 1324-1326. [CrossRef] [PubMed]

18. Smith, B.D. The initial domestication of Cucurbita pepo in the americas 10,000 years ago. Science 1997, 276, 932-934. [CrossRef]

19. FAOSTAT. Available online: http://www.fao.org/statistics/en/ (accessed on 16 August 2019).

20. Wiart, C. Terpenes. In Lead Compounds from Medicinal Plants for the Treatment of Cancer; Wiart, C., Ed.; Academic Press: Cambridge, MA, USA, 2013; pp. 97-265.

21. Napier, T. Pumpkin production. Primefacts 2009, 964, 1-8.

22. OECD. Squashes, pumkins, zucchinis and gourds (Cucurbita species). In Safety Assessment of Transgenic Organisms in the Environment; OECD Publishing: Paris, France, 2016.

23. Andres, T.C. Biosystematics, theories on the origin, and breeding potential of Cucurbita ficifolia (cucurbitaceae). In Biology and Utilization of the Cucurbitaceae; Bates, D.M., Robinson, R.W., Jeffrey, C., Eds.; Cornell University Press: Ithaca, NY, USA, 1990; pp. 102-118.

24. Funt, R.C.; Hall, H.K. Raspberries (Crop Production Science in Horticulture); CAB International: Cambridge, UK, 2013.

25. Esquinas-Alcazar, J.T.; Gulick, P.J. Genetic Resources of Cucurbitaceae: A Global Report; International Board for Plant Genetic Research: Rome, Italy, 1983.

26. Whitaker, T.W. Ecological aspects of the cultivated cucurbita. HortScience 1968, 3, 9-11.

27. Azurdia-Pérez, C.A.; González-Salán, M. Informe Final del Proyecto de Recolección de Algunos Cultivos Nativos de Guatemala; Facultad de Agronomía; Universidad de San Carlos de Guatemala (USAC), Instituto de Ciencia y 
Technología Agrícolas (ICTA) and Consejo Internacional de Recursos Fitogenétic, International Board for Plant Genetic Resources (IBPGR): Guatemala, 1986.

28. Bahlgerdi, M. The Study of Plant Density and Planting Methods on Some Growth Characteristics, Seed and Oil Yield of Medicinal Pumpkin (Cucurbita pepo Var. Styriaca, Cv. Kaki). Am. J. Life Sci. 2014, 2, 319. [CrossRef]

29. Bavec, F.; Gril, L.; Grobelnik-Mlakar, S.; Bavec, M. Seedlings of oil pumpkins as an alternative to seed sowing: Yield and production costs. Bodenkultur 2002, 53, 39-43.

30. Buwalda, J.; Freeman, R. Hybrid squash: Responses to nitrogen, potassium, and phosphorus fertilisers on a soil of moderate fertility. N. Z. J. Exp. Agric. 1986, 14, 339-345. [CrossRef]

31. Reiners, S.; Riggs, D.I. Plant Spacing and Variety Affect Pumpkin Yield and Fruit Size, but Supplemental Nitrogen Does Not. HortScience 1997, 32, 1037-1039. [CrossRef]

32. Swiader, J.M.; Sipp, S.K.; Brown, R.E. Pumpkin Growth, Flowering, and Fruiting Response to Nitrogen and Potassium Sprinkler Fertigation in Sandy Soil. J. Am. Soc. Hortic. Sci. 1994, 119, 414-419. [CrossRef]

33. Manu, V.T.; Holo, T.F.; Pole, F.S.; Halavatau, S.; Kanongata'a, S.; Fakalata, O.K. Conventional Squash Production; Ministry of Agriculture and Forestry: Nukualofa, Tonga, 1995.

34. Bannayan, M. Growth Analysis of Pumpkin (Cucurbita pepo L.) Under Various Management Practices and Temperature Regimes. Agric. Res. Technol. Open Access J. 2017, 11, 555801. [CrossRef]

35. Zitter, T.A. Scab of Cucurbits; Vegetable Crops. Cornell University: Ithaca, NY, USA, 1986; p. 732.50.

36. Nair, P.V.; Thomas, K.G. Hydrazine-Induced Room-Temperature Transformation of CdTe Nanoparticles to Nanowires. J. Phys. Chem. Lett. 2010, 1, 2094-2098. [CrossRef]

37. Colucci, S.J.; Holmes, G.J. Downy mildew of cucurbits. Plant Health Instr. 2010. [CrossRef]

38. Babadoost, M. Phytophthora blight of cucurbits. Plant Health Instr. 2005. [CrossRef]

39. Leibovich, G.; Cohen, R.; Shtienberg, D.; Paris, H.S. Variability in the reaction of squash (Cucurbita pepo) to inoculation with Sphaerotheca fuliginea and methodology of breeding for resistance. Plant Pathol. 1993, 42, 510-516.

40. Nagy, G.S. Studies on powdery mildews of cucurbits. In The Powdery Mildews; Spencer, D.M., Ed.; Academic Press: New York, NY, USA; San Francisco, CA, USA, 1976; Volume 2, pp. 205-210.

41. Egel, D.S.; Martyn, R.D. Fusarium wilt of watermelon and other cucurbits. Plant Health Instr. 2007. [CrossRef]

42. Jahn, M.; Munger, H.M.; McCreight, J.D. Breeding cucurbit crops for powdery mildew resistance. In The Powdery Mildews: A Comprehensive Treatise; Bélanger, R., Bushnell, W.R., Dik, A.J., Carver, T.L.W., Eds.; The American Phytopathological Society: Saint Paul, MN, USA, 2002; pp. 239-248.

43. Zitter, T.A.; Hopkins, D.L.; Thomas, C.E. Compendium of Cucurbit Diseases; APS Press: Saint Paul, MN, USA, 1996; p. 89054.

44. Bradbury, J.F. Guide to Plant Pathogenic Bacteria; CAB International Mycological Institute: London, UK, 1986; p. 334.

45. Rand, R.V. Transmission and control of bacterial wilt of cucurbits. J. Agric. Res. 1916, 6, 417-434.

46. Brunt, A.A.; Crabtree, K.; Dallwitz, M.J.; Gibbs, A.J.; Watson, L.; Zurcher, E.J. Plant Viruses Online: Descriptions and Lists from the Vide Database; CAB International: Wallingford, UK, 1990.

47. Jossey, S.; Babadoost, M. First Report of Tobacco ringspot virus in Pumpkin (Cucurbita pepo) in Illinois. Plant Dis. 2006, 90, 1361. [CrossRef] [PubMed]

48. Metcalf, R.L.; Rhodes, A.M.; Ferguson, J.; Lu, P.-Y. Cucurbitacin Contents and Diabroticite (Coleoptera: Chrysomelidae) Feeding upon Cucurbita spp. Environ. Èntomol. 1982, 11, 931-937. [CrossRef]

49. Nee, M. The domestication of Cucurbita (Cucurbitaceae). Econ. Bot. 1990, 44, 56-68. [CrossRef]

50. Andres, T.C.; Nabhan, G.P. Taxonomic rank and rarity of Cucurbita okeechobeensis. Cucurbit Genet. Coop. Rep. 1988, 11, 83-85.

51. Ward, D.B.; Minno, M.C. Rediscovery of the endangered okeechobee gourd (Cucurbita okeechobeensis) along the st. Johns river, florida, where last reported by william bartram in 1774. Castanea 2002, 67, 201-206.

52. Rymal, K.S.; Chambliss, O.; Bond, M.D.; Smith, D.A. Squash containing toxic cucurbitacin com- pounds occurring in california and alabama. J. Food Prot. 1984, 47, 270-271. [CrossRef] [PubMed]

53. Mi, Y.K.; Eun, J.K.; Young-Nam, K.; Changsun, C.; Bo-Hieu, L. Comparison of the chemical compositions and nutritive values of various pumpkin (cucurbitaceae) species and parts. Nutr. Res. Pract. 2012, 6, 21-27.

54. Amoo, I.A.; Eleyinmi, A.F.; Ilelaboye, N.O.A.; Akoja, S.S. Characterisation of oil extracted from gourd (Cucurbita maxima) seed. J. Food Agric. Environ. 2004, 2, 38-39. 
55. Badr, S.E.; Shaaban, M.; Elkholy, Y.M.; Helal, M.H.; Hamza, A.S.; Masoud, M.S.; El Safty, M.M. Chemical composition and biological activity of ripe pumpkin fruits (Cucurbita pepo L.) cultivated in Egyptian habitats. Nat. Prod. Res. 2011, 25, 1524-1539. [CrossRef]

56. Elinge, C.; Muhammad, A.; Atiku, F.; Itodo, A.; Peni, I.; Sanni, O.; Mbongo, A. Proximate, mineral and anti-nutrient composition of pumpkin (Cucurbita pepo L.) seeds extract. Int. J. Plant Res. 2012, 2, 146-150.

57. Jacobo-Valenzuela, N.; Zazueta-Morales, J.D.J.; Gallegos-Infante, J.A.; Aguilar-Gutierrez, F.; Camacho-Hernandez, I.L.; Rocha-Guzman, N.E.; Gonzalez-Laredo, R.F. Chemical and physicochemical characterization of winter squash (Cucurbita moschata D.). Not. Bot. Horti Agrobot. Cluj-Napoca 2015, 39, 34-40. [CrossRef]

58. Jarret, R.L.; Levy, I.J.; Potter, T.L.; Cermak, S.C.; Merrick, L.C. Seed oil content and fatty acid composition in a genebank collection of Cucurbita moschata Duchesne and C. argyrosperma C. Huber. Plant Genet. Resour. 2013, 11, 149-157. [CrossRef]

59. Mitra, P.; Ramaswamy, H.S.; Chang, K.S. Pumpkin (Cucurbita maxima) seed oil extraction using supercritical carbon dioxide and physicochemical properties of the oil. J. Food Eng. 2009, 95, 208-213. [CrossRef]

60. Murkovic, M.; Hillebrand, A.; Winkler, J.; Leitner, E.; Pfannhauser, W. Variability of fatty acid content in pumpkin seeds (Cucurbita pepo L.). Eur. Food Res. Technol. 1996, 203, 216-219. [CrossRef]

61. Perez Gutierrez, R.M. Review of Cucurbita pepo (Pumpkin) its phytochemistry and pharmacology. Med. Chem. 2016, 6, 012-021. [CrossRef]

62. Younis, Y.; Ghirmay, S.; Al-Shihry, S. African Cucurbita pepo L.: Properties of seed and variability in fatty acid composition of seed oil. Phytochemistry 2000, 54, 71-75. [CrossRef]

63. Noelia, J.; Roberto, M.M.; Jesús, Z.J.D.; Alberto, G.J. Physicochemical, technological properties, and health-benefits of Cucurbita moschata Duchense vs. Cehualca-A review. Food Res. Int. 2011, 44, 2587-2593.

64. Rezig, L.; Chouaibi, M.; Msaada, K.; Hamdi, S. Chemical composition and profile characterisation of pumpkin (Cucurbita maxima) seed oil. Ind. Crop. Prod. 2012, 37, 82-87. [CrossRef]

65. FAO. Vitamin and Mineral Requirements in Human Nutrition; World Health Organization: Geneva, Switzerland, 2005.

66. Fang, S.D.; Li, L.C.; Niu, C.I.; Tseng, K.F. Chemical studies on Cucurbita moschata Duch. I. The isolation and structural studies of cucurbitine, a new amino acid. Sci. Sin. 1961, 10, 845.

67. Azevedo-Meleiro, C.H.; Rodriguez-Amaya, D.B. Qualitative and Quantitative Differences in Carotenoid Composition among Cucurbita moschata, Cucurbita maxima, and Cucurbita pepo. J. Agric. Food Chem. 2007, 55, 4027-4033. [CrossRef] [PubMed]

68. González, E.; Montenegro, M.A.; Nazareno, M.A.; Mishima, B.A.L.D. Carotenoid composition and vitamin A value of an Argentinian squash (Cucurbita moschata). Arch. Latinoam. Nutr. 2001, 51, 395-399. [PubMed]

69. Hidaka, T.; Anno, T.; Nakatsu, S. The Composition and Vitamin A Value of the Carotenoids of Pumpkins of Different Colors. J. Food Biochem. 1987, 11, 59-68. [CrossRef]

70. Murkovic, M.; Mülleder, U.; Neunteufl, H. Carotenoid Content in Different Varieties of Pumpkins. J. Food Compos. Anal. 2002, 15, 633-638. [CrossRef]

71. De Carvalho, L.M.J.; Gomes, P.B.; Godoy, R.L.D.O.; Pacheco, S.; Monte, P.H.F.D.; De Carvalho, J.L.V.; Nutti, M.R.; Neves, A.C.L.; Vieira, A.C.R.A.; Ramos, S.R.R. Total carotenoid content, $\alpha$-carotene and $\beta$-carotene, of landrace pumpkins (Cucurbita moschata Duch): A preliminary study. Food Res. Int. 2012, 47, 337-340. [CrossRef]

72. Azizah, A.; Wee, K.; Azizah, O.; Azizah, M. Effect of boiling and stir frying on total phenolics, carotenoids, and radical scavanging activity of pumpkins (Cucurbita maschato). Int. Food Res. J. 2009, 16, 45-51.

73. Aizawa, K.; Inakuma, T. Quantitation of Carotenoids in Commonly consumed Vegetables in Japan. Food Sci. Technol. Res. 2007, 13, 247-252. [CrossRef]

74. Itle, R.A.; Kabelka, E.A. Correlation between lab color space values and carotenoid content in pumpkins and squash (Cucurbita spp.). HortScience 2009, 44, 633-637. [CrossRef]

75. Chandrika, U.G.; Basnayake, B.M.L.B.; Athukorala, I.; Colombagama, P.W.N.M.; Goonetilleke, A. Carotenoid Content and In Vitro Bioaccessibility of Lutein in Some Leafy Vegetables Popular in Sri Lanka. J. Nutr. Sci. Vitaminol. 2010, 56, 203-207. [CrossRef]

76. Kurz, C.; Carle, R.; Schieber, A. Hplc-dad-msncharacterisation of carotenoids from apricots and pumpkins for the evaluation of fruit product authenticity. Food Chem. 2008, 110, 522-530. [CrossRef] 
77. Konopacka, D.; Seroczyńska, A.; Korzeniewska, A.; Jesionkowska, K.; Niemirowicz-Szczytt, K.; Płocharski, W. Studies on the usefulness of Cucurbita maxima for the production of ready-to-eat dried vegetable snacks with a high carotenoid content. LWT 2010, 43, 302-309. [CrossRef]

78. Rabrenović, B.B.; Dimić, E.B.; Novaković, M.M.; Tešević, V.V.; Basić, Z.N. The most important bioactive components of cold pressed oil from different pumpkin (Cucurbita pepo L.) seeds. LWT-Food Sci. Technol. 2014, 55, 521-527. [CrossRef]

79. Nakić, S.N.; Rade, D.; Škevin, D.; Štrucelj, D.; Mokrovčak, Ž.; Bartolić, M. Chemical characteristics of oils from naked and husk seeds of Cucurbita pepo L. Eur. J. Lipid Sci. Technol. 2006, 108, 936-943. [CrossRef]

80. Eleiwa, N.Z.; Bakr, R.O.; Mohamed, S.A. Phytochemical and Pharmacological Screening of Seeds and Fruits Pulp of Cucurbita moschata Duchesne Cultivated in Egypt. Int. J. Pharmacogn. Phytochem. 2014, 29, 1226-1236. [CrossRef]

81. Li, F.-S.; Xu, J.; Dou, D.-Q.; Chi, X.-F.; Kang, T.-G.; Kuang, H.X. Structures of new phenolic glycosides from the seeds of Cucurbita moschata. Nat. Prod. Commun. 2009, 4, 511-512. [PubMed]

82. Li, F.-S.; Dou, D.-Q.; Xu, L.; Chi, X.-F.; Kang, T.-G.; Kuang, H.X. New phenolic glycosides from the seeds of Cucurbita moschata. J. Asian Nat. Prod. Res. 2009, 11, 639-642. [CrossRef] [PubMed]

83. Li, W.; Koike, K.; Tatsuzaki, M.; Koide, A.; Nikaido, T. Cucurbitosides f-m, aaylated phenolic glycosides from the seeds of Cucurbita pepo. J. Nat. Prod. 2005, 68, 1754-1757. [CrossRef]

84. Yang, R.-Y.; Lin, S.; Kuo, G. Content and distribution of flavonoids among 91 edible plant species. Asia Pac. J. Clin. Nutr. 2008, 17, 275-279.

85. Irshad, M.; Ahmad, I.; Mehdi, S.J.; Goel, H.C.; Rizvi, M.M.A. Antioxidant capacity and phenolic content of the aqueous extract of commonly consumed cucurbits. Int. J. Food Prop. 2014, 17, 179-186. [CrossRef]

86. Sreeramulu, D.; Raghunath, M. Antioxidant activity and phenolic content of roots, tubers and vegetables commonly consumed in India. Food Res. Int. 2010, 43, 1017-1020. [CrossRef]

87. Koo, M.H.; Suhaila, M. Flavonoid (myricetin, quercetin, kaempferol, luteolin and apigenin) content of edible tropical plants. J. Agric. Food Chem. 2001, 49, 3106-3112.

88. Iswaldi, I.; Gómez-Caravaca, A.M.; Lozano-Sánchez, J.; Arráez-Román, D.; Carretero, A.S.; Fernández-Gutiérrez, A. Profiling of phenolic and other polar compounds in Zucchini (Cucurbita pepo L.) by reverse-phase high-performance liquid chromatography coupled to quadrupole time-of-flight mass spectrometry. Food Res. Int. 2013, 50, 77-84. [CrossRef]

89. Tarhan, L.; Kayali, H.A.; Urek, R.O. In Vitro Antioxidant Properties of Cucurbita pepo L. Male and Female Flowers Extracts. Plant Foods Hum. Nutr. 2007, 62, 49-51. [CrossRef] [PubMed]

90. Andjelkovic, M.; Van Camp, J.; Trawka, A.; Verhé, R. Phenolic compounds and some quality parameters of pumpkin seed oil. Eur. J. Lipid Sci. Technol. 2010, 112, 208-217. [CrossRef]

91. Jessica, G.G.; Mario, G.L.; Alejandro, Z.; Cesar, A.P.J.; Ivan, J.V.E.; Ruben, R.R.; Javier, A.-A.F. Chemical Characterization of a Hypoglycemic Extract from Cucurbita Ficifolia Bouche That Induces Liver Glycogen Accumulation in Diabetic Mice. Afr. J. Tradit. Complement. Altern. Med. 2017, 14, 218-230. [CrossRef] [PubMed]

92. Pericin, D.; Krimer, V.; Trivic, S.; Radulovic, L. The distribution of phenolic acids in pumpkin's hull-less seed, skin, oil cake meal, dehulled kernel and hull. Food Chem. 2009, 113, 450-456. [CrossRef]

93. Dubois, M.-A.; Bauer, R.; Cagiotti, M.; Wagner, H. Foetidissimoside A, a new 3,28-bidesmosidic triterpenoid saponin, and cucurbitacins from Cucurbita foetidissima. Phytochemistry 1988, 27, 881-885. [CrossRef]

94. Gaidi, G.; Marouf, A.; Hanquet, B.; Bauer, R.; Correia, M.; Chauffert, B.; Lacaille-Dubois, M.-A. A New Major Triterpene Saponin from the Roots of Cucurbita foetidissima. J. Nat. Prod. 2000, 63, 122-124. [CrossRef]

95. Matus, Z.; Molnár, P.; Szabó, L.G. Main carotenoids in pressed seeds (cucurbitae semen) of oil pumpkin (Cucurbita pepo convar. pepo var. Styriaca). Acta Pharm. Hung. 1993, 63, 247-256.

96. Chen, J.C.; Chiu, M.H.; Nie, R.L.; Cordell, G.A.; Qiu, S.X. Cucurbitacins and Cucurbitane Glycosides: Structures and Biological Activities. Nat. Prod. Rep. 2005, 22, 386-399. [CrossRef]

97. Paryzek, Z. Tetracyclic triterpenes. Part A synthetic approach to cucurbitacins. J. Chem. Soc. 1979, 1, $1222-1227$. [CrossRef]

98. Rehm, S.; Wessels, J.H. Bitter principles of the cucurbitaceae. VIII.-Cucurbitacins in seedlings-Occurrence, biochemistry and genetical aspects. J. Sci. Food Agric. 1957, 8, 687-691. [CrossRef]

99. Metcalf, R.L.; Ferguson, J.E.; Lampman, R.L.; Andersen, J.F. Dry cucubritacin-containing baits for controlling diabroticite beetles (coleoptera chrysomelidae). J. Econ. Entomol. 1987, 80, 870-875. [CrossRef] 
100. Hutt, T.F.; Herrington, M.E. The determination of bitter principles in zucchinis. J. Sci. Food Agric. 1985, 36, 1107-1112. [CrossRef]

101. Ferguson, J.E.; Fischer, D.C.; Metcalf, M. A report of cucurbitacin poisonings in humans. Cucurbit Genet. Coop. Rep. 1983, 6, 73-74.

102. Halaweish, F.T.; Tallamy, D.W. A new cucurbitacin profile for Cucurbita andreana: A candidate for cucurbitacin tissue culture. J. Chem. Ecol. 1993, 19, 1135-1141. [CrossRef]

103. Rehm, S.; Enslin, P.R.; Meeuse, A.D.J.; Wessels, J.H. Bitter principles of the cucurbitaceae. VII.--the distribution of bitter principles in this plant family. J. Sci. Food Agric. 1957, 8, 679-686. [CrossRef]

104. Wang, D.-C.; Pan, H.-Y.; Deng, X.-M.; Xiang, H.; Gao, H.-Y.; Cai, H.; Wu, L.-J. Cucurbitane and hexanorcucurbitane glycosides from the fruits of Cucurbita pepo cv Dayangua. J. Asian Nat. Prod. Res. 2007, 9, 525-529. [CrossRef]

105. Tripathi, J.; Variyar, A.P.; Mishra, P.K.; Variyar, P.S. Impact of radiation processing on the stability of cucurbitacin glycosides in ready-to-cook (RTC) pumpkin during storage. LWT 2016, 73, 239-242. [CrossRef]

106. Kaushik, U.; Aeri, V.; Mir, S.R. Cucurbitacins-An insight into medicinal leads from nature. Pharmacogn. Rev. 2015, 9, 12-18.

107. Bisognin, D.A. Origin and evolution of cultivated cucurbits. Ciência Rural 2002, 32, 715-723. [CrossRef]

108. Rahman, A.H.; Anisuzzaman, M.; Ahmed, F.; Islam, A.K.; Naderuzzaman, A.T. Study of nutritive value and medicinal uses of cultivated cucurbits. J. Appl. Sci. Res. 2008, 4, 555-558.

109. Jayaprakasam, B.; Seeram, N.P.; Nair, M.G. Anticancer and antiinflammatory activities of cucurbitacins from Cucurbita andreana. Cancer Lett. 2003, 189, 11-16. [CrossRef]

110. Gill, N.S.; Bali, M. Isolation of antiulcer cucurbitane type triterpenoid from the seeds of Cucurbita pepo. Res. J. Phytochem. 2011, 5, 70-79. [CrossRef]

111. Le Roux, G.; Leborgne, I.; Labadie, M.; Garnier, R.; Sinno-Tellier, S.; Bloch, J.; Deguigne, M.; Boels, D. Poisoning by non-edible squash: Retrospective series of 353 patients from French Poison Control Centers. Clin. Toxicol. 2018, 56, 790-794. [CrossRef] [PubMed]

112. Pfab, R.; Oefele, H.; Pietsch, J.; Kapp, T.; Zellner, T.; Eyer, F. Revenge of the zucchinis-Is this the result of climate change? Clin. Toxicol. 2016, 54, 501.

113. Stoewsand, G.S.; Jaworski, A.; Shannon, S.; Robinson, R.W. Toxicologic Response in Mice Fed Cucurbita Fruit. J. Food Prot. 1985, 48, 50-51. [CrossRef] [PubMed]

114. Wu, H.; Zhu, J.; Diao, W.; Wang, C. Ultrasound-assisted enzymatic extraction and antioxidant activity of polysaccharides from Pumpkin (Cucurbita moschata). Carbohydr. Polym. 2014, 113, 314-324. [CrossRef]

115. Yang, X.; Zhao, Y.; Lv, Y. Chemical Composition and Antioxidant Activity of an Acidic Polysaccharide Extracted from Cucurbita moschata Duchesne ex Poiret. J. Agric. Food Chem. 2007, 55, 4684-4690. [CrossRef]

116. Pakrokh Ghavi, P. Modeling and optimization of ultrasound-assisted extraction of polysaccharide from the roots of althaea officinalis. J. Food Process. Preserv. 2015, 39, 2107-2118. [CrossRef]

117. Xia, T.; Wang, Q. D-chiro-Inositol found in Cucurbita ficifolia (Cucurbitaceae) fruit extracts plays the hypoglycaemic role in streptozocin-diabetic rats. J. Pharm. Pharmacol. 2006, 58, 1527-1532. [CrossRef] [PubMed]

118. Rodríguez, R.R.; Valdés, R.M.; Ortiz, G.S. Características agronómicas y calidad nutricional de los frutos y semillas de zapallo Cucurbita sp. Rev. Colomb. Cienc. Anim. RECIA 2018, 10, 86-97. [CrossRef]

119. Wightii, B.S.S. Extraction and characterisation of polysaccharides from leaflets. Life Sci. 2012, 7, 17-69.

120. Yuan, G.F.; Chen, X.E.; Li, D. Conjugated linolenic acids and their bioactivities: A review. Food Funct. 2014, 5, 1360-1368. [CrossRef] [PubMed]

121. Pokora, M.; Zambrowicz, A.; Eckert, E.; Pokora, M.; Bobak, Ł.; Da, A. Antioxidant and antidiabetic activities of peptides isolated from a hydrolysate of an egg- yolk protein by-product prepared with a proteinase from Asian pumpkin (Cucurbita ficifolia). RSC Adv. 2016, 5, 10460-10467.

122. Wroc, T.T. Egg-yolk protein by-product as a source of ace-inhibitory peptides obtained with using (Cucurbita ficifolia). J. Proteom. 2016, 110, 107-116.

123. Köksal, E.; Bursal, E.; Aggul, A.G.; Gulcin, I. Purification and Characterization of Peroxidase from Sweet Gourd (Cucurbita moschata Lam. Poiret). Int. J. Food Prop. 2012, 15, 1110-1119. [CrossRef]

124. Chonoko, U.G.; Rufai, A.B. Phytochemical screening and antibacterial activity of curbita pepo (pumpkin) against staphylococcus aureus and salmonella typhi. J. Pure Appl. Sci. 2011, 4, 145-147. 
125. Dinu, M.; Soare, R.; Hoza, G.; Becherescu, A.D. Biochemical Composition of Some Local Pumpkin Population. Agric. Agric. Sci. Procedia 2016, 10, 185-191. [CrossRef]

126. Adeel, R.; Sohail, A.; Masud, T. Characterization and antibacterial study of pumpkin seed oil (Cucurbita pepo). Life Sci. Leafl. 2014, 49, 53-64.

127. Abed El-Aziz, A.; Abed El-Aziz, H. Antimicrobial proteins and oil seeds from pumpkin. Nat. Sci. 2011, 9 , 105-119.

128. Zhou, C.-L.; Liu, W.; Zhao, J.; Yuan, C.; Song, Y.; Chen, D.; Ni, Y.-Y.; Li, Q.-H. The effect of high hydrostatic pressure on the microbiological quality and physical-chemical characteristics of Pumpkin (Cucurbita maxima Duch.) during refrigerated storage. Innov. Food Sci. Emerg. Technol. 2014, 21, 24-34. [CrossRef]

129. Dar, A.H.; Sofi, S.A. Pumpkin the functional and therapeutic ingredient: A review. Int. J. Food Sci. Nutr. 2017, 2, 165-170.

130. Muruganantham, N.; Solomon, S.; Senthamilselvi, M.M. Anti-cancer activity of Cucurbita maxima flowers (pumpkin) against human liver cancer. J. Aournal Pharmacogn. Phytochem. 2016, 6, 1356-1359.

131. Cheong, N.E.; Choi, Y.O.; Kim, W.Y.; Bae, I.S.; Cho, M.J.; Hwang, I.; Kim, J.W.; Lee, S.Y. Purification and characterization of an antifungal PR-5 protein from pumpkin leaves. Mol. Cells 1997, 7, 214-219. [PubMed]

132. Barbieri, L.; Polito, L.; Bolognesi, A.; Ciani, M.; Pelosi, E.; Farini, V.; Jha, A.K.; Sharma, N.; Vivanco, J.M.; Chambery, A.; et al. Ribosome-inactivating proteins in edible plants and purification and characterization of a new ribosome-inactivating protein from Cucurbita moschata. Biochim. Biophys. Acta 2006, 1760, 783-792. [CrossRef] [PubMed]

133. Park, S.-C.; Kim, J.-Y.; Lee, J.-K.; Hwang, I.; Cheong, H.; Nah, J.-W.; Hahm, K.-S.; Park, Y. Antifungal Mechanism of a Novel Antifungal Protein from Pumpkin Rinds against Various Fungal Pathogens. J. Agric. Food Chem. 2009, 57, 9299-9304. [CrossRef]

134. Salehi, B.; Capanoglu, E.; Adrar, N.; Catalkaya, G.; Shaheen, S.; Jaffer, M.; Giri, L.; Suyal, R.; Jugran, A.K.; Calina, D.; et al. Cucurbits Plants: A Key Emphasis to Its Pharmacological Potential. Molecules 2019, $24,1854$. [CrossRef]

(C) 2019 by the authors. Licensee MDPI, Basel, Switzerland. This article is an open access article distributed under the terms and conditions of the Creative Commons Attribution (CC BY) license (http://creativecommons.org/licenses/by/4.0/). 